\title{
Biological Effects of Plant Lectins on the Gastrointestinal Tract: Metabolic Consequences and Applications
}

\section{植物レクチンの消化器系への生物学的作用: 代謝に対する影響と応用}

\author{
Pusztai, A.; and Bardocz, S. \\ The Rowett Research Institute, Bucksburn, Aberdeen, AB2 9SB, Scotland, UK, \\ FAX: 44-1224-716687 or 44-1224-716616, E-mail: ajp@ rri.sari.ac.uk
}

Key Words: drug delivery, lectins, probiosis, signalling, transgenic plants

\begin{abstract}
Lectins are one of the most important physiologically active ingredients and potent exogeneous biological signals in the diet. Although the amounts of lectins in foodstuffs can vary considerably, they can dramatically affect the entire digestive tract and its bacterial population, body metabolism and health. Their extraordinary effectiveness stems from resistance to gut proteolysis and a high and specific chemical reactivity with endogenous surface receptors of the epithelial cells of the gut of both higher animals and lower organisms. Lectins are powerful oral and parenteral immunogens and some of their physiological effects are intricately linked to interference with immune function. However, the primary effects and the potency of lectins as biological signals are the direct result of their specific chemical reactivity with saccharides. As these reactions are predictable, the use of lectins as blockers of pathogens, immune stimulants, hormone modulators and metabolic agents in clinical-medical applications and as natural insecticides in transgenic plants, offers great promise.
\end{abstract}

\section{A. Introduction}

Lectins are carbohydrate-binding (glyco)proteins of non-immune origin capable of specific recognition of, and reversible binding to, carbohydrates without altering their covalent structure (1). Ligand-binding which is the first step in the reaction between lectins and carbohydrates is similar for both lectins and carbohydrate-reactive enzymes. However, the subsequent steps are different because, in contrast to the action of enzymes, formation of the lectin-sugar complex is not followed by splitting of chemical bonds in the covalent structure of the carbohydrate ligands nor the dissociation of the complex.

Lectins occur widely in plants (for refs. see 2). Consequently, most plant-based food/feed stuffs contain appreciable amounts of lectins, some with striking biological activities on gut function. Although in general lectins are more resistant to heat-denaturation than other plant proteins, legume lectins can be inactivated by moderately prolonged cooking. However, as heat-processing is expensive and potentially damaging, it is
要 約

食物に含まれるレクチンは、生理活性を持つ成分として重 要であり、強力な外来性のシグナルとなる。食物中のレクチン の含量は大きく異なるが、消化管全体に劇的な影響を与え、消 化管内の細菌の数、体の代謝、健康にも大きく影響する。レク チンの強い効果は、腸におけるタンパク質分解に対する抵抗性、 腸の上皮細胞表面(高等動物から下等生物に至るまで)に発現し ている内在性受容体に対する特異的、かつ高い化学反応性に由 来する。経口であれ、非経口的であれ、取り込まれたレクチン は強力な免疫原となり、その生理作用が複雑にからみあって免 疫機能に干渉することもある。しかし、レクチンの初期効果や バイオシグナルとしての能力は、糖鎖との特異的な化学反応の 直接の結果である。こういった反応を想定すれば、レクチンを 臨床医学的に、病原体、免疫系刺激物質、ホルモン調節因子、代 謝活性化物質の阻害剂として利用したり、トランスジェニック 植物における内在性の殺虫剂として利用するといったことが将 来的に見込める。

A. はじめに

レクチンは糖鎖を特異的に認識して可逆的に結合する(共 有結合を切らない)糖結合タンパク質(レクチン自身が糖鎖を持 つこともある)で、糖鎖を認識する抗体は含まない (1)。レクチ ンと糖鎖の反応の第一段階であるリガンド結合は、糖鎖に対す る酵素の場合と似ているが、それ以降のステップは酵素の場合 と異なる。なぜなら、䣲素の作用と異なり、レクチンと糖の複 合体が形成されても、その後で糖りガンド内の共有結合が切れ たり、複合体が再び解離したりすることがないからである。

レクチンは植物で幅広く分布している(2)。したがって、植 物を基本とする食料や食餌はほとんど全て、かなりの量のレク チンを含み、なかには、腸の機能に対して著しい生物活性を示 すものもある。一般的にレクチンは他の植物タンパク質に比べ て熱による変性に強いが、マメ科のレクチンは穏やかに長めに 調理すれば不活化できる。しかし、熱処理には経費がかかり、素 材を損なう可能性も高いので、マメ類でさえもできるだけ短時 
usually kept to a minimum even with legumes, particularly when the product is to be used in animal nutrition. Furthermore, as many non-legume lectins are not denatured by normal heating practices and green vegetables and fruits are usually not cooked, the digestive tract is regularly exposed to biologically active lectins. Moreover, cooking and other heat-treatments are recent inventions of the human civilisation, therefore exposure to dietary lectins must have played an important part in the evolutionary development of alimentary tract of both humans and higher animals.

As lectins react with the surface epithelium of the digestive tract, they can cause antinutritional, mild allergic or other subclinical effects in higher animals and humans, particularly when consumed in large quantities (2). The importance of understanding of the precise mechanism of these diet-gut interactions and the ensuing effects on metabolism is self-evident. However, studies of the effects of lectins on the gut have revealed that oral administration of low doses of lectins can also have many beneficial effects on the digestive/absorptive efficiency of the gut, its immune system and bacterial ecology and that, by modulating the secretion of gut hormones, some lectins can influence the body's endocrine system with beneficial consequences for general metabolism (3). It is becoming clear that with these potentially wide range of applications, lectins may provide one of the practical and most natural means for improving both the nutritional value and safety of the diet.

The realisation that lectins may have many potential uses has been given an added impetus by the recent discovery that some lectins are far more toxic for insects than for higher animals (4). It is therefore possible that some crops are naturally resistant to pests because their constituent lectin interacts strongly with the surface glycosyl groups of the less highly differentiated cells of the insect digestive tract. This may then lead to potent inhibition of the process of food assimilation in the insect gut with severe consequences for their survival and reproduction. Thus, some lectins are regarded as natural insecticides. Moreover, with the advent of genetic engineering it is now possible to transfer lectin genes into plants which do not normally possess these and therefore protect important and sensitive crop plants against harmful pests without using chemical insecticides and pesticides (4).

\section{B. Lectin - Gut Interactions}

\section{B-1. Resistance of Plant Lectins to Proteolytic Degradation}

Dietary proteins are rapidly degraded during passage through the gut by digestive enzymes in the small bowel. Any residual undigested matter is then degraded by bacteria in the large intestine and used as sources of energy. In contrast to dietary proteins, lectins resist degradation in the small intestine (5) and are also resistant to breakdown by most gut bacteria. Thus, as most lectins survive at least in part the passage through
間の熱処理で済まされる。特に、動物の飭にするときはそうな りがちである。さらに、多くのマメ類に由来しないレクチンは 通常の熱処理では失活しないし、緑色野菜や果物は調理されな いことが多いので、消化管は常に生物活性を持ったレクチンに さらされている。しかも、調理や他の加熱処理は人類の文明に よって最近なされた発明だから、食物中のレクチンにさらされ ることは、ヒトや他の高等動物の消化管が進化にともなって発 達してきた過程に重要な意味を持っていたに違いない。

レクチンは消化管の表面上皮と反応するので、特に大量に 摂取すると、反栄養的な効果、弱いアレルギー性の効果、ある いは他の潜在的な効果をヒトや他の高等動物に対して示す (2)。 こういった、食物と腸の相互作用、代謝に対する影響の正確な メカニズムを理解することは非常に重要である。しかし、レク チンの腸への作用を調べた結果、少量のレクチンの経口摂取は、 腸の消化吸収の効率や、免疫系、細菌の環境に様々なよい影響 を与えるということ、また、腸ホルモンの分泌を調節すること により体の内分泌系システムに影響を与えて、全体の代謝に有 利な結果をもたらすレクチンもあるということがわかってきた (3)。こういった広範囲な応用が期待できることから、食物の栄 養価と安全性の両方を高めるために、レクチンが実用的で最も 自然な手段を提供しうることが明らかになりつつある。

高等動物よりも昆虫に対してはるかに強い毒性を示すレク チンが存在することが最近わかり (4)、レクチンには様々な潜在 的用途がありうるとの認識が高まっている。ある種の作物が害 虫に抵抗性を示すのは、構成成分として存在するレクチンが、 その虫の消化管の細胞表面の分化が十分でない糖鎖と強く相互 作用するためであるとも考えられる。この結果、昆虫の腸にお いて食物消化のプロセスが強く阻害され、虫は生存や繁殖に重 大な影響を受ける。このような理由で、天然の殺虫剤だと考え られているレクチンがある。さらに、遺伝子工学技術の到来に より、本来はレクチンを持たない植物にレクチン遺伝子を導入 し、虫害に弱い貴重な穀類を化学殺虫㓮を用いずに害虫から守 ることが可能になった (4)。

\section{B. レクチンと腸の相互作用}

\section{B-1. 1 植物レクチンのタンパク質分解抵抗性}

食物中のタンパク質は、腸を通過するとき、小腸の消化酵 素によって素早く分解される。消化しきれなかったものは大腸 の微生物により分解され、エネルギー源となる。反対に、レク チンは小腸に扔ける分解に抵抗性を示し(5)、さらに、ほとんど の腸内細菌による分解に対しても抵抗性を示す。それゆえ、ほ 
Table I. Survival and binding of pure lectins to the small intestinal mucosa*.

\begin{tabular}{llll}
\hline Lectins & Specificity & Binding & Recovery (\%) \\
\hline PHA (Phaseolus vulgaris) & Complex & +++ & $>90$ \\
Con A (Canavalia ensiformis) & Man/Glc & + & $>90$ \\
GNA (Galanthus nivalis) & Man & - & $>90$ \\
SNA-I (Sambucus nigra) & $\alpha-2,6-$ neuraminyl-Gal & + & $50-60$ \\
SNA-II " " & GalNAc & +++ & $>60$ \\
SBA (Glycine max) & GalNAc/Gal & ++ & $40-50$ \\
LEL (Lycopersicon esculentum) & GlcNAc & + & $40-50$ \\
WGA (Triticum vulgare) & GlcNAc & ++ & $50-60$ \\
PSL (Pisum sativum) & Man/Glc & \pm & $30-40$ \\
VFL (Vicia faba) & Man/Glc & \pm & $20-30$ \\
DGL (Dioclea grandiflora) & Man/Glc & \pm & $18-20$ \\
& & &
\end{tabular}

Rats were intragastrically intubated with $10 \mathrm{mg}$ of individual lectins. The amounts of lectin surviving in the stomach and small intestine were estimated from luminal washings and supernatants of the tissues homogenized with $0.1 \mathrm{M}$ solution of the appropriate specific carbohydrate in phosphate-buffered saline, $\mathrm{pH}$ 7.6. The strength of binding is marked on an arbitrary scale: +++ strong binding and - represents no binding at all. *From ref. no. 5.

the digestive tract in an immunologically and functionally intact form (Table I), they can exert their potent biological activities in vivo. Similar to the enhanced stability of hormones and growth factors bound to receptors, lectins are also protected by receptor-binding. However, this is not necessary as shown by the almost complete survival of the agglutinin from Galanthus nivalis, snowdrop bulbs (GNA) which does not bind to the gut wall on acute oral exposure suggesting that resistance may also result from particular features of the molecular structure (6).

As part of the normal turnover of the gut epithelium, cells are shed from the villus tips into the lumen and most cellular material is then digested and recycled. The presence of lectins attached to these cells does not interfere with the breakdown of cell contents but the liberated lectin can move further down the gut and bind to the next receptor with an appropriate carbohydrate moiety. Although lectin-binding is most frequently studied in the small intestine, similar binding can occur throughout the entire digestive tract, from the stomach to the distal colon. However, as surface glycosylation varies in the different functional parts of the gut, lectin-binding is not uniform in the digestive tract. Thus, when a particular glycosyl group is absent from the surface of the small bowel but present on the large intestinal epithelium, specific lectin-binding will almost exclusively be to the wall of the colon and vice versa. Accordingly, with the appropriate choice of lectins, it is possible to selectively affect the metabolism of different parts of the gut.

As some lectins are partially heat-stable and most remain active during the passage through the gut, interactions be-
とんどのレクチンが、消化管を通過しても少なくとも一部が免 疫学的にも機能的にも無傷のまま生き残り(表 I)、その強力な生 物活性をin vivoで発揮しうる。ホルモンや堌殖因子が受容体に 結合すると、安定性が増すように、レクチンも受容体に結合す ると保護される。しかし、必ずしも受容体結合しなくてもよい ようであり、一時的に経口摂取されたマツユキソウ Galanthus nivalis の球根の凝集素(GNA)が腸壁に結合しなかったが、ほぼ 無傷であったという例がある。消化に対する抵抗性は分子構造 の特別な性質によるのかもしれない(6)。

腸上皮の正常なターンオーバーの一段階として、細胞は絊 毛の先端からはがれて内腔に落ちて、細胞由来の物質はほとん ど消化され再利用される。レクチンがこういった細胞に結合し ていても細胞の内容物の分解を邪魔することはないが、自由に なったレクチンは腸内をさらに移動して、適当な糖鎖を持った 次の受容体に結合できる。レクチンの結合は小腸において最も 詳しく研究されているが、似たような結合は消化管全体 (胃か ら結腸にいたるまで) のどこでも起こりうる。ただし、機能が 異なる腸の各部位では表面の糖鎖も異なるので、レクチン結合 も消化管全体で一様ではない。それゆえ、ある種の糖鎖が小腸 の表面には存在せず、大腸の上皮に存在するならば、特異的な レクチン結合はもっぱら結腸壁で起こることになるし、その逆 の場合もありうる。したがって、レクチンをうまく選べば、腸 の部位を選択して代謝に影響を与えることも不可能ではない。

熱に対してある程度安定なレクチンが存在し、そのほとん どは腸を通過しても活性を維持するので、食物中のレクチンと 
tween lectins in the diet and the gut can occur, occasionally with dramatic consequences. Although it is known from animal studies that lectins can damage the gut and this may lead to various nutritional disorders (for refs., see 2), it is not generally appreciated that this only occurs at relatively high lectin concentrations in the diet. However, lectins can also have beneficial effects particularly at low dietary inclusions, and these may find uses in medical/clinical practice (3).

\section{B-2. Carbohydrate Structures on the Surface of the Gut}

The surface epithelium of the gut is extensively glycosylated (7-10) mainly because most membrane proteins including hormone and growth factor receptors, transport proteins and brush-border enzymes are glycosylated before being embedded in the brush-border membrane.

Additionally, membrane lipids and gangliosides are also glycosylated, and all secreted mucins are carbohydrate-rich glycoproteins. Accordingly, the scope of potential lectin-gut interactions is wide. However, for these reactions to occur it is necessary that the correct carbohydrate structures should be present on the surface of the gut mucosa, i.e. the one which the lectin is specific for. Thus, despite extensive glycosylation of the surface of the alimentary tract, not all lectins react with the epithelium and even those which react vary in their ability to recognise and bind to specific types of carbohydrate receptors. Moreover, the structure of glycosyl side-chains depends on many factors even within one species, such as the age of the animal, its blood group specificity, genetics, the mucosal cell types and their state of differentiation/maturation and position on the crypt/villus axis and along the gastrointestinal tract (Table II). For example, it is believed that the glycosyl sidechains of membrane glycoproteins of the less differentiated crypt cells are usually of the polymannose type, whereas the fully mature cells on the villi express complex glycosyl sidechains.

The epithelium of the small bowel is composed of a monolayer of epithelial enterocytes whose main function is to digest and absorb the nutrients. These cells are interspersed with minor cell types: mainly goblet cells producing mucins,
腸の相互作用は時に劇的な結果をもたらすこともある。動物実 験から、レクチンが腸に傷害を与えてさまざまな栄養障害をも たらす例が知られているが(2)、これは食物中にレクチンがかな り多く含まれる場合にのみ見られるということはあまり知られ ていない。一方、レクチンは、食物中の含量が低い場合、生体 にとって有益な効果を持っこともしばしばあり、医学的臨床的 に応用できるかもしれない (3)。

\section{B-2. 腸の表面の糖構造}

腸の上皮表面は広範囲にわたってグリコシル化されている (7-10)。その主な理由は、ホルモン受容体や増殖因子受容体、輸 送タンパク質、刷子縁の酵素などの膜タンパク質のほとんどが、 刷子縁膜に埋め込まれる以前にグリコシル化を受けるからである。

それに加えて、膜の脂質やガングリオシドもグリコシル化 されているし、分泌されるムチンもすべて糖鎖が沢山ついた糖 タンパク質である。したがって、一ロにレクチンと腸の相互作 用といっても広範囲にわたる。しかし、こういった反応が起こ るには、腸の粘膜の表面に適切な、すなわち、問題としている レクチンが特異的に認識する糖構造が存在しなければならない。 それゆえ、消化管表面が高度にグリコシル化されているといっ ても、すべてのレクチンが上皮と反応するとは限らない。たと え反応するとしても、特定の糖受容体を認識して結合する能力 は様々である。さらに、糖構造は様々な要因によって変わりう る。たとえ同じ動物種であっても、年齢、血液型の特異性、遺 伝的要因、粘膜細胞の細胞型や分化成熟における段階、絨毛か ら陰窩へ向かう座標軸上でどの位置にあるか、胃から腸にかけ ての位置などによって、それぞれの糖構造は異なるのである (表II)。例えば、分化が進んでいない陰窩細胞の膜タンパク質の 糖鎖は通常高マンノース型であるとされているが、緁毛まで達 した成熟細胞は複合型の糖鎖を発現している。

小腸の上皮は上皮腸細胞の単層からなっている。その主要 な機能は食物を消化し吸収することである。このすきまに副次 的な細胞が点在している。ムチンを産生する杯細胞と腸のペプ チドホルモンを合成する腸分泌細胞である。小腸の上皮は機能

Table II. Factors influencing membrane glycosylation in the intestines.

$\begin{array}{ll}* & \text { Animal species } \\ * & \text { Blood group specificity } \\ * & \text { Age } \\ * & \text { Site in the intestines } \\ * & \text { Position along crypt - villus axis } \\ * & \text { Stem cell genetics } \\ * & \text { State of differentiation and maturation } \\ * & \text { Diet } \\ * & \text { Bacterial status } \\ * & \text { Pathology }\end{array}$


and enteroendocrine cells, which are responsible for the synthesis of gut peptide hormones. The small intestinal epithelium is organized into two functionally and morphologically distinct compartments: the crypts, where stem cells proliferate and differentiate, and the villi, where these differentiated cells mature while migrating toward the tip of the villi. During migration along the crypt-villus axis, there is a continuous change in the cellular membrane; its protein composition, the pattern and activity of the enzymes expressed in it and the state of glycosylation of its components go through distinct phases of development. Finally, after the mature cells have reached the apical area of the villus, they are extruded into the lumen.

As all cell-surface proteins have to be transported from the site of synthesis to the plasma membrane, they have to go through several steps of glycosylation. However, the pattern of glycosylation of the membrane glycoconjugates varies in different species. Indeed, this great variability in membrane glycosylation may help to explain why lectins differ in their ability to interact with the gut surface (6). Unfortunately, at present, quantitative information on the precise carbohydrate structure of the gut surface receptors, their location along the crypt-villus axis and the changes occurring during normal turnover or under different conditions of age and dietary status, is limited. However, the epithelium of the intestinal tract has one of the highest cell turnover rates in the body which enables it to react rapidly to dietary changes. Moreover, surface morphology of the gut and changes in its receptors follow and can truly reflect the causes which initiated these changes. Indeed, mapping the lectin receptor sites by lectin-histochemistry and/or determination of their lectin-binding capacity can give valuable information on the functional state of the gut.

\section{B-3. Lectin-induced Changes in Cell Metabolism}

As surface membrane receptors of cells are glycosylated, lectins are good mimics of the effects of endogenous growth factors, hormones and cytokines in all types of cells (for ref., see 2). Receptor proteins are usually composed of more than one subunit. The signal molecules bind to the subunits exposed on the external side of the membrane and these are glycosylated. The other subunit(s) span the membrane, and these are responsible for the transmission of the signal message and the activation of the second messenger system(s). Depending on their position, the sugar-structures can be present on or near to the active centre of the receptor. Although the lectin binding site (the glycosyl side chains) is clearly not the normal functional binding site of the receptor, the resulting conformational change in the receptor subunits embedded in the membrane and the ensuing signal transduction may be similar irrespective of whether the activation was by the physiological ligand or the lectin. In this case the lectin can mimic the effect of the natural ligand and induce similar physiological reactions. However, it is also possible that the bound lectin may not in-
的にも形態学的にも異なった 2 種類の部分から組織されている。 陰窝 (幹細胞が増殖分化する) と絨毛である (分化した細胞が絨 毛の先端へ向かって移動しながら成熟していく)。陰窩から絨 毛へ向かって移動していく間に細胞膜は連続的に変化していく。 タンパク質の組成、酵素の発現パターン、活性、構成物質のグ リコシル化の段階などは、分化のうえではっきり異なっている。 成熟細胞が絨毛のアピカル側にたどりつくと、最終的に内腔に 押し出される。

細胞表面タンパク質は全て、合成された場所から形質膜へ 運ばれなければならないので、グリコシル化のいくつかの段階 を通らなければならない。しかし、膜上の複合糖質のグリコ シル化のパターンは種類によって異なる。確かに、膜のグリコ シル化に多様性があるということで、なぜ腸表面と相互作用す る能力がレクチンごとに違うのか説明できそうである(6)。しか し残念ながら、腸表面受容体の正確な糖構造、その陰窩絨毛軸 上での分布の状況、正常にターンオーバーしているときと、年 齢や食餌状態が変わったときでの糖鎖の变化などについて定量 的な情報は今のところきわめて少ない。しかし、腸管の上皮細 胞のターンオーバーの速度は体の中でも最も速く、食餌の変化 に迅速に対応できる。さらには、腸表面の形態や受容体の変化 は、その変化をもたらした原因を忠実に反映している。レクチ ン組織化学によってレクチン受容体の分布やレクチン結合能を 調べれば、腸の機能がどうなっているのかについて有益な情報 が実際に得られる。

\section{B-3. レクチンによって誘導される細胞の物質代謝の変化}

細胞膜上の受容体はグリコシル化されているので、あらゆ る種類の細胞において、レクチンは内在性の増殖因子やホルモ ン、サイトカインと似た効果を示すことが多い(2)。受容体タン パク質は複数のサブユニットからできているのが普通である。 シグナル分子は細胞膜の外側に露出しているサブユニットに結 合するが、このサブユニットはグリコシル化されている。それ 以外のサブユニットは膜を貫通し、シグナルの伝達やセカンド メッセンジャー系の活性化に関わっている。受容体に付加して いる糖構造が、受容体分子の活性中心やその近傍に存在する場 合もある。レクチンが結合する部位 (糖側鎖) が、受容体の本来 の機能的結合部位でないことは明らかであるが、膜に埋め込ま れた受容体サブユニットに活性化の原因となったのが、生理的 リガンドであろうとレクチンであろうと関係なく、同じような コンホメーション変化とそれに付随する情報伝達を誘導するこ ともあり得る。その場合、レクチンは天然のリガンドの効果を 模倣して、生理的な応答を引き出すことができる。その一方で、 受容体に結合したレクチンがコンホメーション変化を誘導する 
Trends in Glycoscience and Glycotechnology Vol. 8 No. 41 (May 1996) pp.149-165

duce a conformational change but, by physically blocking the active site of the receptor, attenuate or completely abolish the physiological effect of the natural ligand. Some of the so-called non- or anti-mitogenic lectins probably fall into this category. Finally, lectin-binding to the external receptor subunits may also additively or synergistically reinforce the effects of the natural ligand by an allosteric mechanism.

\section{B-4. Interaction with the Brush Border Membrane}

For a lectin to exert its biological activity, the carbohydrate structure which it is specific for, must be present and free on the gut surface. The interaction between them can be best described by a key-lock analogy. If both the lectin (key) and receptor (lock) are present, the binding is immediate and the lectin can open the lock and send messages into the cell via second messengers or by the lectin itself entering the cell. Either way, the lectin can influence the metabolic activity of gut epithelial cells or, for that matter, any other cell.

Recognition between lectins and receptors is instantaneous. However, the strength of the binding is dependent on the association constant between the lectin and the glycosyl group and the number of unoccupied receptor sites. If there are many carbohydrate side-chains with the 'right' sugar structure, the lectin will bind extensively and cross-link them. With only few sites, particularly when they are well-separated, only weak or no binding occurs. Moreover, lectins which avidly bind to epithelial cells are also readily endocytosed and transcytosed although the signals necessary for these processes are not well understood (6).

Lectins which bind avidly to the brush border membrane are potent hyperplastic growth factors for the gut $(2,5)$. Indeed, lectin-binding to the epithelium is obligatory for growth stimulation and their growth factor activity is determined mainly by the strength and intensity of their binding (6). Thus, the kidney bean (Phaseolus vulgaris) agglutinin, PHA, is one of the most avidly binding lectins and also one of the most potent intestinal growth factors $(5,6,11)$. Although during this growth the length of the villus is rarely affected significantly, the size of the crypts, the number of cells they contain and the crypt cell production rate (CCPR) are substantially increased and with continuous exposure to PHA, the cell turnover time can decrease from 72 to $12 \mathrm{~h}$. However, while during the hyperplastic growth cell migration on the villi speeds up, the time taken for cellular differentiation remains unchanged. Consequently, there is an increase in the proportion of immature cells on the villi whose protein and enzyme patterns are typical of the immature cell type. This is clearly shown by the reduction in the amounts/activity of maturation marker enzymes, such as diamine oxidase (12) or sucrase-isomaltase and alkaline phosphatase in gut tissues (unpublished). As a result, the capacity of cells to digest/absorb nutrients is reduced.

With other lectins similar changes may occur. How-
代わりに、受容体の活性部位を物理的に阻害して天然リガンド の生理的な効果を弱めたり、あるいは完全に消失させたりする こともあり得る。いわゆる「マイトジェン活性を持たないレク チン」はおそらくこの部類に入るだろう。細胞外の受容体サブ ユニットにレクチンが結合し、アロステリックなメカニズムに より、天然のリガンドの効果を相加的または相乗的に増強する 場合もある。

\section{B-4. 刷子縁膜との相互作用}

レクチンが生物活性を示すためには、そのレクチンに特異 的な糖構造が腸の表面に存在し、しかもフリーでなければなら ない。レクチンと糖との相互作用は鍵と鍵穴に例えられる。レ クチン (鍵) とその受容体 (鍵穴) の両方が存在すれば、結合は 直ちに起こり、レクチンは屝を開けて情報を伝えることができ る。これはセカンドメッセンジャーを介したり、レクチン自身 が細胞内に入ることで行われる。いずれにしても、レクチンは 腸の上皮細胞の代謝活性に影響を与えることができ、他の細胞 に対しても同様だろう。

レクチンと受容体との間で認識は瞬時に起こる。しかし、 結合の強さはレクチンと糖との間の結合定数や、占有されてい ない受容体結合部位の数に依存する。もしレクチンに正しく対 応した糖鎖が多ければ、レクチンは十分に結合してその糖鎖を 架橋するだろう。結合できる部位がほとんどなく特にそれらが 離れて存在するときは、結合は非常に弱いか起こらない。さら に、上皮細胞に強く結合するレクチンはどれも容易に細胞内に とりこまれたり、細胞を横切ったりする。しかしこのプロセス に必要なシグナルはよくわかっていない (6)。

刷子縁膜に強く結合するレクチンは腸にとって強い增殖因 子である (2、5)。実際、増殖刺激には上皮へのレクチンの結合 が必須であり、主に、レクチンの結合の強さによって增殖因子 としての活性が決まる (6)。それゆえ、インゲンマメ (Phaseolus vulgaris) 凝集素PHAは最も結合が強く、腸の増殖因子として最 も活性が強い (5、6、11)。PHA 刺激による増殖の際には、絨毛 の長さが大きく影響を受けることはまれだが、陰窩の大きさや、 その中の細胞数、陰窩細胞産生速度 (CCPR) は有意に増加し、 PHAに長くさらしておくと、細胞のターンオーバーの時間が72 時間から 12 時間へと減少する。しかし、䋐毛における增殖細胞 の移動が速くなっても、この細胞が分化に要する時間は変わら ない。その結果、絨毛では未成熟細胞 (タンパク質や酵素のパ ターンが未成熟細胞に典型的なもの) の割合が増加する。それ は成熟のマーカー酵素 [ジアミンオキシダーゼ (12) や、腸組織 のスクロースイソマルターゼとアルカリホスファターゼ (未発 表)など]の量や活性が減少することからはっきりとわかる。そ の結果、細胞が食物を消化吸収する能力は弱まっている。

他のレクチンでも似たような変化が起こりうる。しかしこ 
ever, these are dependent on the strength of lectin-binding which correlates well with their effectiveness as growth factors. Even when binding is relatively weak, lectins can disturb the organization of the epithelial membrane by cross-linking surface receptors, and induce slight gut growth.

In adult rats there are few free terminal mannose residues on the brush-border membranes (7), therefore, on acute exposure the binding of the mannose-specific GNA to the jejunal epithelium is slight and no growth occurs. Interestingly, Concanavalin A (Con A) from jack bean (Canavalia ensiformis), which has a similar specificity reacts somewhat more strongly than GNA, but due to patchy binding there is only slight growth (7). In contrast, as on the luminal surface mainly complex glycosyl groups are expressed, PHA-binding is extensive. Due to the presence of $N$-acetylglucosamine in hybrid glycosyl moieties in brush border enterocytes, wheat (Triticum vulgare) germ agglutinin (WGA) also binds well and is endocytosed $(7,13)$, particularly at mid villus, though this also occurs lower down on the villi.

\section{B-5. Binding and Endocytosis by the Stomach and the In- testines}

Although studies in model systems have indicated that reaction between most lectins and their specific ligands is abolished at acid $\mathrm{pH}$ ( $\mathrm{pH} 3$ or less), lectins can apparently bind to the stomach epithelium in vivo even when the luminal $\mathrm{pH}$ is 3 or less $(14,15)$. This may, in part, explain why the presence of lectins in the diet slows down stomach-emptying in rats.

Binding of lectins and their endocytosis by enterocytes occurs throughout the gut although endocytosis in the small intestine becomes appreciable only in the presence of large numbers of commensal bacteria. As expected, endocytosis of lectins is more extensive in the colon where bacterial counts are high (14). Thus, lectins may be particularly suited to serve as site-directed targeting agents for delivering drugs to the colonic epithelium (16).

\section{B-6. Effects of Plant Lectins on the Gut Immune System}

Type-1, immediate hypersensitivity reactions by the gut immune system occur even to highly degradable food proteins. Allergic reactions to the more stable lectins which persistently bind to brush border cells can be more extensive (for refs., see 2 ). Thus, the anaphylactic response of the gut to PHA, as assessed from the leakage of ${ }^{125}$ I-labelled serum proteins into the gut of rats given a single intragastric dose of lectin, is appreciable even on first exposure. This increased vascular permeability is not IgE-mediated but due to the direct degranulation of submucosal mast cells by PHA (17) and cross-linking of membrane glycans by the multivalent PHA. However, the allergic response was elevated in rats pre-fed on PHA-diets, suggesting that it was amplified by the formation of anti-PHA $\operatorname{IgE}$ (17).
れはレクチンの結合活性の強さに依存し、それに増殖因子とし ての有効性も関係している。結合が割合に弱いときも、レクチ ンは表面受容体を架橋して上皮膜の構成を乱し、腸の成長を多 少なりとも誘導しうる。

成熟ラットでは刷子縁膜上に末端マンノース残基が露出し ていることはほとんどない (7)。それゆえ、空腸の上皮が突然、 ンノース特異的なGNAにさらされたとしても、結合するものは わずかで、增殖も起こらない。括もしろいことに、タチナタマ メ (Canavalia ensiformis) から得られるコンカナバリン A (Con A) は、糖特異性が似ていて、GNAよりもいくぶん強く反応する が、結合がまばらなのでわずかしか増殖させない (7)。その一 方、主に複合型糖鎖が発現している内腔表面ではPHAが顕著に 結合する。刷子縁膜の腸細胞では混成型糖鎖にN-アセチルグル コサミンが存在するので、コムギ (Triticum vulgare) 胚凝集素 (WGA) も強く結合し、エンドサイトーシスされるが (7、13)、 これは特に絨毛の中央部で起こる(絨毛の下部でも起こる)。

B-5. 胃と腸における結合とエンドサイトーシス

モデル系の実験からほとんどのレクチンでは、その特異的 リガンドとの反応が酸性 $\mathrm{pH}$ ( $\mathrm{pH} 3$ 以下) で失われることがわ かっているが、胃の上皮では内腔の $\mathrm{pH}$ が3以下であってもレク チンは明らかに結合することが in vivo 実験で示されている(14、 15)。ラットで飭にレクチンが含まれると、胃が空になるスピー ドが遅くなることをこのことである程度説明できるかもしれな w。

腸細胞へのレクチンの結合とエンドサイトーシスは腸全体 で起こるが、小腸におけるエンドサイトーシスは、共生細菌が 大量に存在するときにのみ認められる。細菌の数が多い結腸で、 レクチンのエンドサイトーシスがより顕著なのは予想通りであ る(14)。それゆえ、レクチンを結腸の上皮へ部位選択的に薬物 を運ぶ、ターゲティングのための道具として利用することも考 えてよいだろう (16)。

\section{B-6. 腸の免疫系への植物レクチンの効果}

非常に消化のよい食物タンパク質に対しても、腸の免疫系 はI型の即時型過敏反応を起こす。もっと安定で、刷子縁細胞に 持続的に結合するレクチンに対するアレルギー反応がもっと強 く出てもおかしくない (2)。それゆえ、PHAに対する腸のアナ フィラキシー反応 (胃内に 1 回レクチンを投与したラットの腸 にもれてくる ${ }^{22} I$ 標識した血清タンパク質で測定する)は最初の 投与でも認められる。こうした血管透過性の増大は IgEを介す るものではなく、PHAによる粘膜下組織中の肥満細胞の直接の 脱顆粒 (17) と、多価性のPHAによる膜グリカンの架橋による。 しかし、PHAをあらかじめ与えておいたラットでは、アレル ギー反応が増強された。これはPHAに対するIgEが作られたこ とを示唆している (17)。 


\section{Modification of Epithelial Cell Glycosylation by Lectins}

Depending on the specificity of the lectin and the strength of its binding, three main types of lectin-induced changes were observed in the glycosylation of membrane and/ or cytoplasmic glycoproteins of epithelial cells of the small intestine.

\section{C-1. Effect of Increased Crypt Cell Production Rate (CCPR) on Glycosylation}

After exposure to lectins which bind avidly to and are endocytosed extensively in the small intestine, the pattern of glycosylation of brush-border cells becomes distinctly different from that of fully mature apical cells in control rats. In particular large amounts of polymannosyl groups are exposed on both membrane and cytoplasmic glycoconjugates, readily detectable by histological staining with GNA-digoxigenin (7). It is possible that with the lectin-induced increase in CCPR and the correspondingly shortened transit time, the less differentiated crypt cells, which are highly polymannosylated, penetrate further up the villus than they would under normal physiological conditions. The more reactive the lectins are, the shorter the transit time becomes, with the result that there are more immature cells on the epithelial surface which contain more polymannosyl side-chains in the cellular glycoproteins. Accordingly, the most effective growth-stimulating lectins are also the most powerful agents for inducing this type of change in carbohydrate receptor expression of the gut epithelium.

\section{C-2. Reaction of Lectins with Secreted Glycoproteins}

Lectins which react with sialic acid in secreted glycoproteins, such as those from the bark of the elder tree (Sambuccus nigra), SNA-I, and Maackia amurensis, MAA, can induce changes in receptor glycosylation by overstimulating and exhausting the capacity of goblet cells to synthesise mucin (7). The action of these lectins results in the partial disappearance of mucin 'receptor sites' containing neuraminyl$\alpha 2,6$-lactose and neuraminyl- $\alpha 2,3$-lactose glycosyl structures respectively, and this may leave the luminal surface partially uncovered. Thus, the reactivity of the intestinal epithelium with SNA-I or MAA disappears almost completely after extended dietary exposure to these lectins. As the binding of soya bean (Glycine max) agglutinin, SBA, to glycans with terminal sialic acid is relatively weak, the extent of its binding is increased after the removal of mucins containing terminal sialic acid.

\section{C-3. Displacement of Endogenous Ligands by Dietary Lectins}

By displacing endogenous ligands bound to glycosyl moieties of luminal receptors, lectin can change the availability of glycosyl groups on the membrane. Thus, GNA-binding by the small intestinal brush-border is essentially nil in rats with a conventional microflora but is significant in germ-free animals (7). This may reflect the fact that Escherichia coli or other mannose-sensitive fimbriated bacteria can block the limited

\section{C. 上皮細胞のグリコシル化に対するレクチンの効果}

小腸上皮細胞の膜あるいは細胞質にある糖タンパク質のグ リコシル化の状態が、レクチンにより変化させられるが、これ はレクチンの特異性と結合の強さにより大きく 3 タイプに分け ることができる。

\section{C-1. 陰窩細胞産生速度 (CCRP) の増加がグリコシル化に与え る影響}

小腸に強く結合し迅速にエンドサイトーシスされるレクチ ンにさらされると、コントロールのラットの充分成熟したアピ カル細胞にくらべ、刷子縁細胞のグリコシル化のパターンは はっきりと異なってくる。GNA-ジゴキシゲニンを用いた組織 染色により (7)、膜と細胞質両方の複合糖質に、ポリマンノース が特に多量に露出されてくることが容易に検出できる。レクチ ンによりCCPRが増加し、それに呼応して移動時間が短くなり、 陰窩細胞の成熟が充分でなくなり、より高度にポリマンノシル 化され、正常な生理的条件に比べて絨毛上をより高くまで進む、 というスキームが考えられる。レクチンの反応性が高まるほど 移動時間が短くなり、その結果、上皮表面の未成熟細胞（細胞 の糖タンパク質により多くのポリマンノース側鎖を持つ) がよ り多くなるのである。それゆえ、増殖刺激の効率が最も高いレ クチンは、腸上皮の糖受容体発現におけるこういったタイプの 变化の誘導においてももっとも強い作用を持つ。

\section{C-2. 分泌された糖タンパク質とのレクチンの反応}

ニワトコ (Sambuccus nigra) 樹皮のレクチン SNA-Iや Maackia amurensis のレクチンMAAなどのように、分泌された 糖タンパク質のシアル酸と反応するレクチンは、杯細胞のムチ ン合成を過剩に刺激して、合成能を疲弊させることにより受容 体のグリコシル化に変化を誘導できる(7)。これらのレクチンの 作用により、ラクトースにノイラミン酸が $\alpha 2,6$ 結合または $\alpha$ 2,3 結合した糖構造を持つムチンの「受容体部位」が部分的に消 失し、その結果、内腔の表面が部分的に露出するといったこと が起こりうる。それゆえ、食物中のこれらのレクチンに持続的 にさらされると、腸上皮の SNA-Iや MAA に対する反応性がほ ぼ完全に消失する。末端シアル酸を介したダイズ (Glycine max) 凝集素SBAのグリカンへの結合はそれに比べると弱いので、末 端シアル酸を持つムチンが除かれると SBAの結合量は増大す る。

\section{C-3. 食物中のレクチンによる内在性リガンドの置換}

内腔に存在する受容体の糖部分に結合した内在性のリガン ドを取り除くことにより、レクチンは膜の糖グループの利用度 を変えることができる。それゆえ、小腸の刷子縁へのGNAの結 合は、通常の微生物叢を持つラットでは実質的にゼロであるが、 無菌の動物では有意に見られる (7)。このことは、大腸菌や他の 
number of surface mannosyl groups but these groups are free in the absence of bacteria in the lumen $(6,7)$. However, when lectin concentration in the lumen is high during feeding rats diets containing GNA, the newly emerging epithelial cells may bind the GNA in preference to the bacteria.

\section{C-4. Nutritional Penalty of Growth Stimulation}

The hyperplastic growth of the gut has a nutritional penalty for the animal, since the need to renew the gut surface more quickly than normal means that more of the dietary protein and energy are used up to maintain the faster turnover (18). However, this may be offset by the gain in absorption efficiency of the fresh gut surface after the removal of the lectin from the diet. With lectins which are powerful growth factors for the small bowel, the cost in nutritional terms can be appreciable. At very high dietary intakes of these lectins, most or all of the diet is used by the gut alone with the result that other organs are starved of nutrients. However, as in practice the dietary intake of lectins is low, their growth stimulating activity has no measurably negative effect on nutritional performance.

\section{Effect of Lectins on Gut Bacteria}

It has recently been demonstrated that the orally administered lectins which are generally regarded as toxic are not deleterious per se but that most of their harmful consequences are due to their interaction with gut bacteria (19-24). Although PHA and other so-called "toxic" lectins bind just as extensively to the epithelium and stimulate the growth of the small intestine of germ-free rats as they do in rats carrying a conventional microflora, the consequences of the binding are essentially harmless for the germ-free rats $(2,19,20)$. The deleterious effects of the consumption of large amounts of PHA by animals with a normal microbial flora are probably due to the stimulation of a selective bacterial overgrowth in the small intestine by the lectin. This may be exacerbated by the increased endocytosis by the epithelial cells of PHA and possibly the bacteria and/or their toxic metabolites or toxins. After transcytosis, these toxic substances may enter the blood circulation and exert their deleterious effects by stopping vital body functions. They may also interfere with the body's hormone balance and disturb normal metabolic reactions.

\section{D-1. Direct Interaction of Lectins with Gut Bacteria}

Lectins can directly interact with and agglutinate some resident bacteria of the digestive tract and then selectively remove these from the lumen. Therefore, diets which contain these lectins can change the bacterial ecology of the gut. However, lectins can also interfere with the attachment of bacteria to the brush border by speeding up the turnover of epithelial cells and, by changing receptor glycosylation, effectively remove potential attachment sites for particular bacteria.
マンノース感受性采状細菌が表面の限られた数のマンノースグ ループをブロックできるが、このマンノースグループは内腔に 細菌がいなくなるとフリーとなるという事実を反映しているの かもしれない (6、7)。ただし、ラットにGNAを含む食餌を与え ていて内腔のレクチン濃度が高いときには、新しく出てくる上 皮細胞は、細菌よりもむしろ GNAを結合するのかもしれない。

\section{C-4. 増殖刺激による栄養上の不利益}

腸において細胞が増殖すると動物にとって栄養上は不利益 を被ることになる。というのは、腸の表面を通常よりも速く新 しくしなければならないということは、速くなった代謝回転を 維持するために食物中の夕ンパク質とエネルギーがより多く消 費されることを意味するからである (18)。しかし、食物中のレ クチンが除かれた後、新しい腸表面で吸収効率を増大すること によりこの不利益は相補されるかもしれない。小腸に対して強 力な増殖因子となるレクチンでは栄養上の不利益が見受けられ る。こういったレクチンを大量に摂取すると、ほとんどの、場 合によっては全ての食物が腸だけで使われ、その結果、他の臓 器では栄養分が枯渴する。ただし、通常は食物中からのレクチ ンの摂取は少ないので、レクチンの増殖刺激活性は栄養撕取に 不利益となるような効果を示さない。

\section{D. レクチンが腸内細菌に与える影響}

口から摂取すると、有毒だと一般的に考えられてきたレク チンは、それ自体が有害なのではなく、ほとんどの場合、腸内 細菌と相互作用した結果、有害となることが最近明らかにされ た (19-24)。PHA や他のいわゆる「有毒な」レクチンは、通常 の腸内細菌を保持しているラットと同様に、無菌的なラットの 上皮に強く結合し、小腸の増殖を刺激するが、無菌的なラット には実質的に無害である $(2 、 19 、 20)$ 。通常の腸内細菌を持つ動 物に大量にPHAを摄取させると、毒性が見られるのは、おそら く、PHAによって小腸内の特定の細菌の過度な増殖が刺激され るからだと考えられる。この毒性は、PHA、そしてたぶん、細 菌またはその毒性代謝物や毒素に対する、上皮細胞のエンドサ イトーシスが増すと悪化する。細胞を横切って取り込まれると、 こういった毒素は血流中に入り、生命維持に不可欠な生体機能 を止めてしまうことにより毒性を発揮するのかもしれない。さ らに、体のホルモンバランスを妨害したり、代謝反応を阻害し たりするかもしれない。

\section{D-1. レクチンの腸内細菌との直接の相互作用}

消化管の中で生息している細菌の中には、レクチンが直接 相互作用して凝集させ、選択的に内腔から取り除かれるものが ある。それゆえ、こういったレクチンを含む食物は、腸内の細 菌分布を変えることもある。しかしながらレクチンは、上皮細 胞のターンオーバーを速くすることにより細菌の刷子縁への接 着を阻害することもあり、受容体のグリコシル化を変えること により特定の細菌の結合部位を効率的に取り除くこともある。 
Table III. PHA Dose-dependence of $E$. coli overgrowth in the rat small intestine.

\begin{tabular}{lcc}
\hline $\begin{array}{l}\text { Dose of PHA } \\
\text { mg/rat/day }\end{array}$ & \multicolumn{2}{c}{$\log _{10}$ counts of E. coli } \\
& Washed & Unwashed \\
\hline 24 & & $4.8 \times 10^{4}$ \\
28 & - & $5.9 \times 10^{5}$ \\
44 & - & $5.5 \times 10^{5}$ \\
50 & - & $6.9 \times 10^{6}$ \\
54 & - & $6.8 \times 10^{6}$ \\
58 & $1.0 \times 10^{7}$ & $6.6 \times 10^{6}$ \\
66 & $0.9 \times 10^{8}$ & $1.0 \times 10^{9}$ \\
72 & $9.0 \times 10^{8}$ & $9.0 \times 10^{8}$ \\
78 & - & $2.0 \times 10^{8}$ \\
80 & - & $1.0 \times 10^{8}$ \\
98 & - & $3.2 \times 10^{7}$ \\
\hline
\end{tabular}

\section{D-2. Lectin-induced Coliform Overgrowth in the Small In- testine}

The stability of the bacterial flora in the small intestine of healthy, well-fed rats was clearly demonstrated by our inability to orally infect them with Type-1, mannose-sensitive fimbriated E. coli isolated from their own gut without first changing their diet (24). Even after six days of oral exposure of the rats to broth containing $10^{8}$ and $10^{9}$ viable E. coli $\mathrm{ml}^{-1}$, coliform counts remained at control levels, $10^{3}$ to $10^{4}$, in the whole small intestine. In contrast, a highly significant, dosedependent and damaging but fully reversible overgrowth of $E$. coli occurred in the small bowel of rats given PHA in the diet (Table III). The source of $E$. coli for this selective overgrowth was the commensal flora. Although at high doses of PHA there was also a slight increase in some non-lactose-fermenting coliforms (mainly Proteus spp.), counts of Lactobacillus spp. and Bacteroides were essentially unchanged even at the highest PHA concentrations. The proliferating E. coli was avidly bound to the small intestinal glycocalix and could not be removed by simple washing of small intestinal sections unless mannose was used in the washing buffer. This provides convincing experimental evidence for the involvement of bacterial lectins in the adhesion of bacteria to the small intestinal epithelium.

Similar overgrowth of the small intestine by commensal, Type-1, mannose-sensitive fimbriated $E$. coli can be induced by other avidly binding lectins, such as SBA, WGA or Robinia lectin, although to achieve the same effect their amounts have to be increased to compensate for the lower avidity of their binding.

Morphological studies have confirmed that $E$. coli over-
D-2. レクチンによって誘導される小腸における大腸菌群の過㮃 な増殖

ラットの腸から単離したマンノース感受性の1型采状大腸 菌を食餌を変えることなしに口から与えても感染させられない ことから、健康で食餌も十分に与えられたラットでは、腸内細 菌が安定であることがはっきりとわかった (24)。1 mlあたり $10^{8}$ から $10^{9}$ 個の生きた大腸菌を含む肉汁をラットに6日間食べさせ ても、小腸全体での大腸菌群の数は $10^{3}$ から $10^{4}$ 個とコントロー ルレベルのままであった。その反対に、食餌中にPHAを与えた ラットの小腸では、はっきりと有意に、濃度依存的に、そして 有害性を示すぐらい、しかし完全に可逆的に大腸菌が過度に増 殖していた (表III)。この選択的な過増殖の大腸菌源は共生して いる腸内細菌であった。高濃度のPHAでも非ラクトース発酵大 腸菌群 (主にProteus属)がわずかに増加しており、Lactobacillus 属や Bacteriodes 属はPHA の濃度を最高にしてもほとんど変わ らなかった。増殖している大腸菌は小腸の糖衣に強く結合して おり、小腸切片を単に洗っただけでは除くことができず、洗浄 緩衝液にマンノースを加えて初めて取り除くことが可能となっ た。このことは、細菌のレクチンが小腸上皮への接着に関与し ていることを示す有力な実験上の証拠となる。

共生するマンノース感受性の 1 型采状大腸菌の小腸に扔け る過増殖は、強く結合する他のレクチン、例えば、SBA、WGA、 Robiniaレクチンなどによっても誘導される。もっとも、同じ効 果を得るには、結合がPHAよりは弱い分を補うために量を増や さなければならない。

形態学的な研究から、小腸における大腸菌の過増殖は、強 
growth in the small intestine occurs only with lectins which are potent growth factors. As explained above, in healthy rats the villus epithelium is populated mainly by highly differentiated, mature enterocytes expressing complex saccharide groups and only few terminal $\alpha$-linked mannose residues on membraneand cytoplasmic glycoconjugates. Thus, in the normal rat small intestine the residual population of Type-1, mannose-sensitive fimbriated $E$. coli is low. This is confirmed by the near absence of binding of GNA but a high reactivity with PHA. However, after PHA-induced overgrowth of $E$. coli, $\alpha$-linked terminal mannosyl groups become numerous as shown by strong reaction with GNA $(7,24)$ and, as the brush-border can now provide receptors for the bacteria, selective proliferation ensues. The overgrowth is reversible because the mannosyl residues disappear within three days of the removal of the PHA from the diet.

Lectin-induced coliform overgrowth is not confined to laboratory conditions. Injuries to the small intestinal epithelium automatically stimulate its hyperplastic growth to make good the damage regardless of whether it is caused by dietary or bacterial lectins or other erosive factors or diseases. Under these conditions the proportion of immature cells expressing polymannosylated membrane and cytoplasmic glycans increase inevitably leading to coliform overgrowth. The resulting diarrhoea and other digestive/absorptive problems usually exacerbate the initial gut damage and, when combined with poor nutritional status such as in children from Third World countries, may lead to serious and wide-ranging health problems.

\section{D-3. Prevention of Colonization of the Gut by Pathogens} Using Dietary Lectins (Chemical Probiosis)

Bacterial overgrowth in the small intestine is a major cause of ill-health and of production loss in farm animals. Control by antibiotics is not always possible because this may give rise to the development of antibiotic-resistance. Moreover, the methods proposed for the reduction of harmful bacteria in the small intestine by administration of sugars or complex carbohydrates are somewhat ineffective. In contrast, lectins such as GNA and possibly other non-toxic lectins are highly effective
い増殖因子活性を持つレクチンのみが起こせることが確かめら れた。先に説明したように、健常なラットでは、緁毛の上皮に おいては、高度に分化した成熟腸細胞が主要なものとなる。こ の細胞は複合型の糖鎖を発現しており、膜でも細胞質でも複合 糖鎖の末端に $\alpha$ 結合したマンノースがみられることはほとんど ない。それゆえ、正常ラットの小腸では、残存するマンノース 感受性の 1 型采状大腸菌の数は少ない。このことは、GNA 結合 活性がほとんど見られないのに、PHA反応性が高いことからも 確かめられる。しかしながら、PHAによって誘導される大腸菌 の過増殖の後、 $\alpha$ 結合した末端マンノースはおびただしい数と なり (GNA 反応性が強くなることからわかる) (7、24)、刷子縁 が細菌に対する受容体を供与できるようになるので選択的な増 殖が続いて起こる。この過増殖は可逆的である。なぜなら食餌 中から PHA を除く, と 3 日以内にマンノース残基が消失するか らである。

レクチンによって誘導される大腸菌群の過増殖は、実験室 内の条件でのみ起こるわけではない。小腸上皮に傷害が起こる と自動的に、被害を埋め合わせするために増殖が刺激される。 その傷害の原因が食餌あるいは細菌のレクチンであろうが、あ るいは他のびらん性の因子でも病気でも関係ない。このような 条件下では、ポリマンノースを持つ膜あるいは細胞質グリカン を発現している未成熟細胞の割合が必然的に増加し、大腸菌群 が過増殖する。結果として起こる下痢や他の消化吸収障害は通 常、最初に起こる腸のダメージをいっそう悪化させる。これが、 第三世界の国の子供達のように栄養不足を伴うと、深刻で広範 な健康障害に至ることがあり得る。

\section{D-3. 食餌中のレクチンを用いた、病原体の腸への集落形成の阻} 害 (化学的共生)

小腸における細菌の過増殖は、病気や、家畜の生産性の低 下の主要な原因である。抗生物質による制御はいつも可能とは 限らない。なぜならば抗生物質耐性を生じさせるかもしれない からである。糖や複合糖質の投与により小腸の有害な細菌を減 らすという方法もあまり効果がない。その一方、GNAや他の無 害のレクチンはラットの小腸において 1 型の大腸菌の過増殖を

Table IV. Microbiological analysis of the small intestine (jejunum) of rats treated with PHA (kidney bean lectin) in the presence or absence of GNA (snowdrop bulb lectin) and appropriate controls*.

Treatment groups
LA (control) GNA+PHA
PHA
GNA
$\mathrm{PHA} \rightarrow \mathrm{LA} \quad$ SED

$\log _{10} \quad$ Bacterial counts $\mathrm{g}^{-1}$ wet tissue

Lactose fermentor coliforms

Non lactose-fermentor coliforms

Lactobacilli

$\begin{array}{ll}3.3^{\mathrm{a}} & 6.5^{\mathrm{b}} \\ 2.8^{\mathrm{a}} & 4.8^{\mathrm{b}} \\ 4.2^{\mathrm{a}} & 6.4^{\mathrm{b}}\end{array}$

$6.5^{b}$

$6.4^{\mathrm{b}}$

$8.7^{\mathrm{c}}$
$5.8^{\mathrm{c}}$
$7.4^{\mathrm{c}}$

$8.7^{\mathrm{c}}$

$7.4^{\mathrm{c}}$ $3.1^{\mathrm{a}}$

$2.8^{\mathrm{a}}$

$4.7^{\mathrm{a}}$ $3.3^{\mathrm{a}}$

$2.7^{\mathrm{a}}$

$2.8^{\mathrm{d}}$
0.9

0.6

1.0

Groups $(n=12)$ of rats were fed on different diets: LA, control lactalbumin for $6 \mathrm{~d}$; GNA+PHA, GNA incorporated into control diet for $6 \mathrm{~d}$ and intubated with PHA for the last $3 \mathrm{~d}$; PHA, control diet for $6 \mathrm{~d}$ and intubated with PHA for the last $3 \mathrm{~d}$; GNA, GNA incorporated into control diet for $6 \mathrm{~d}$ and PHA $\rightarrow \mathrm{LA}$, control diet for $6 \mathrm{~d}$ and intubated with PHA for the first $3 \mathrm{~d}$. Groups with different superscripts in horizontal rows are significantly different (at least $\mathrm{P}<0.05$ ). *From ref. no 24 . 
in inhibiting the overgrowth of Type- $1 E$. coli in the rat small intestine (Table IV). However, this can only happen if the sugar- specificity of the blocker lectin is complementary to that of the bacterial adhesin (24).

Non-toxic lectins are good candidates to replace antibiotics because they can be administered with the diet and therefore may provide the most natural means for the control of pathogenic infection. Thus, lectin research and exploration of their ability to block bacterial adherence in the gut (Chemical probiosis) may ultimately lead to the discovery of strategies for the prevention of intestinal disease and improvements in food safety.

\section{E. Systemic Effect of Lectins}

Lectins may influence systemic metabolism by two different but possibly simultaneous mechanisms (for refs., see 2). Lectins can indirectly influence the endocrine system of the body by binding to the neuroendocrine cells of the gut and stimulating the secretion of gut peptide hormones into the systemic circulation. Alternatively, lectins can be transmitted through the gut wall into the blood circulation and thus may directly influence peripheral tissues and body metabolism by mimicking the effects of endocrine hormones. The organs most often affected are the pancreas, skeletal muscle, liver, kidneys and thymus (25).

\section{E-1. Oral Immunization}

Although most food proteins are rapidly degraded in the small intestine, nutritionally insignificant amounts are absorbed systemically through $\mathrm{M}$ cells of the gut-associated lymphoid tissue and presented by macrophages to competent lymphocytes of the immune system (for refs., see 2). Allergic responses to these absorbed proteins in adults are minimized by $\mathrm{T}$ suppressor cells and therefore harmful effects seldom occur and only in susceptible individuals. In contrast, as luminal levels of the more stable lectins are high, their transport through the gut wall is appreciable. Thus, PHA is a powerful oral immunogen and produces a high titre of monospecific anti-PHA antibody of IgG-type in animals, including ruminants $(26,27)$. There is, in fact, some evidence that most lectins given orally are immunogenic (28). The recent finding of high titre anti-banana lectin (BanLec-1) $\mathrm{IgG}_{4}$ antibodies in pooled human blood further supported this suggestion (29).

The time-course of antibody development follows the normal course of immunization with a primary response by ten days after the first oral dose. Further oral exposure results in booster effects. Thus, the putative gut anti-lectin-s-IgA system must be ineffective since it cannot prevent the absorption of PHA (2). This abrogation of s-IgA response to PHA may remove one of the major obstacles to the repeated use of lectintargeted oral drug conjugates.

Lectins can modulate IgE responses to other antigens.
阻害するのに高い効果があった (表IV)。ただし、阻害作用を持 つレクチンの糖特異性が細菌のアドヘシンと相補的であった場 合のみ有効であった (24)。

毒性を持たないレクチンは抗生物質にとってかわれる優れ た候補である。なぜなら、レクチンは食物の中に加えて投与す ることができるので、病原体の感染を最も自然にコントロール できる手段となりうるからである。それゆえ、レクチンを研究 し、腸の中において細菌の接着を阻害 (化学的共生)できる能力 を検索することは、究極的には、腸の疾病防止の戦略の発見や 食物の安全性の向上に至るだろう。

\section{E. レクチンが体全体に及ぼす効果}

レクチンは2つの異なった (しかし同時に働いていると思 われる) メカニズムにより全身の代謝に影響を与えうる (2)。レ クチンは、腸の神経内分泌細胞に結合して、腸のペプチドホル モンの体循環への分泌を刺激することにより、体の内分泌系に 間接的に影響を与えることができる。一方、レクチンは腸壁を 通って血液循環に運ばれ、内分泌性のホルモンの作用を模倣す ることにより、末梢組織や体の代謝に直接影響を与えることも できる。最も影響を受けやすいのが膵臓、骨格筋、肝臓、腎臓、 そして胸腺である (25)。

\section{E-1. 経口免疫}

食物タンパク質は大部分が小腸ですばやく分解されるが、 栄養学的にはさほど重要でない量が腸と結合したリンパ組織の M細胞によって全身にわたって吸収され、マクロファージによ り免疫系のコンピーテントなリンパ球に提示される(2)。こうし て吸収されたタンパク質に対して大人が示すアレルギー反応は、 サプレッサー T細胞により最小限度に抑えられ、体に有害な効 果は、感受性の高い個体を除いてほとんど見られない。その反 対に、より安定なレクチンでは内腔における濃度が高いため、 腸壁を通した輸送がみられる。それゆえ、PHAは強力な経口免 疫源であり、動物 (反易動物を含む) において、力価が高く単 一特異性を持つ IgG タイプの抗 PHA 抗体を作らせる (26、27)。 実際、経口的に与えられたレクチンのほとんどは免疫原性を持 つという形跡もみられる (28)。最近高い力価の抗バナナレクチ ン (BanLec-1) 抗体 $\left(\mathrm{IgG}_{4}\right)$ が、ヒトの貯留血液中に存在すると いうことがわかり、この示唆をさらに支持した (29)。

抗体形成の経過は通常の免疫と同様な道をたどり、最初の 経口投与から 10 日以内には初期応答がみられる。さらに経口で とり続けると、ブースター効果が現れる。それゆえ、腸にある と考えられる抗レクチン-s-IgAシステムは効果がないに違いな い。なぜなら PHA の吸収を抑えることができないからである (2)。PHA に対する s-IgA 応答を排除すれば、レクチンで誘導さ れる経口投与薬物複合体を繰り返し用いることに対して障害と なっている一つの原因を取り除けるかもしれない。

レクチンは他の抗原に対する IgE 応答を調節できる。Con 
Table V. Effect of lectins and trypsin inhibitor on the pancreas*.

\begin{tabular}{lccc}
\hline & Weight & Acinar area & Polyamines \\
\hline PHA & 145 & 156 & 140 \\
RPA; Robina & 143 & n.d. & 126 \\
SNA-II; Elder & 136 & 150 & 140 \\
SBA; Soya & 132 & 145 & 153 \\
WGA; Wheat germ & 118 & n.d. & 114 \\
DSA; Datura & 111 & n.d. & 101 \\
UDA; Nettle & 98 & n.d. & 94 \\
SBA-I; Elder & 132 & 132 & 133 \\
MAA; Maackia & 132 & 132 & 106 \\
STI; Trypsin inhibitor & 135 & 151 & 160 \\
\hline
\end{tabular}

The weight, acinar area of true tranverse pancreatic sections (stained with haematoxylin and eosin, perimeter traced by computer-linked pixel planimetry and measured by a Joyce-Loebl 'Magiscan' image analyser) and polyamine content of pancreas of rats fed with diets containing $0.7 \%$ lectins or trypsin inhibitor are expressed relative to those of the controls (taken as $100 \%$ ). *From ref. no 33.

Thus, although both Con-A and PHA affect the synthesis of anti-ovalbumin IgE in mouse, Con-A enhances it under most conditions(30), while the effect of PHA depends on the time of injection (31). In DBA/2 mice parenterally immunised with ovalbumin, oral sensitisation to jacalin (jackfruit, Artocarpus heterophyllus, lectin) increased IgE responses to both jacalin and ovalbumin in a time- and dose-dependent way. This suggested that jacalin is a mitogenic immunomodulator for the production of $\operatorname{IgE}$ but not IgG antibodies against these two antigens (32). Thus, the use of lectins to reduce or abolish IgE responses to allergens without affecting the synthesis of IgGtype humoral antibodies, promises well for the future treatment of allergies.

\section{E-2. Effects of Dietary Lectins on the Pancreas}

Most dietary lectins produce trophic changes within the exocrine pancreas which parallel the growth of the small intestine (Table V). The best known example is PHA, which is a growth factor for both the gut and pancreas. The trophic effect of lectins on the pancreas is mainly mediated through cholecystokinin $(\mathrm{CCK})$, a gut peptide hormone which is released by PHA action from duodenal enteroendocrine cells. The growth of the pancreas is intimately involved with polyamine metabolism in the tissue (Table V). However, the mechanism of lectininduced, polyamine-dependent pancreatic growth appears to involve a route of hormonal mediation which is, at least in part, different from that caused by soya trypsin inhibitors despite that both are mediated by cholecystokinin (33).

As secretion of digestive enzymes by the pancreas is severely reduced in chronic pancreatitis, it is possible that the administration of low doses of non-toxic lectins which stimulate pancreatic hypertrophy may find use in clinical practice. This is because lectins in contrast to trypsin inhibitors, do not inhibit
A と PHAのいずれもがマウスにおいて抗オボアルブミン IgEの 合成に影響を与えるが、Con Aがほとんどの条件で (30) 増強す るのに対し、PHAの影響は投与の時間に依存する (31)。親に才 ボアルブミンを免疫した DBA/2マウスで、ジャカリン[パラミ ツ(Artocarpus heterophyllus) レクチン〕を経口により感作すると、 ジャカリンとオボアルブミン両方に対する IgE 応答が、時間依 存的、濃度依存的に増強された。このことは、ジャカリンがこ れら 2つの抗原に対する $\left(\mathrm{IgG}_{1}\right.$ ではなく) $\mathrm{IgE}$ 産生させるよう なマイトジェン活性を持った免疫調節因子であることを示唆す る(32)。それゆえ、 IgG 型の体液性抗体の合成に影響を与える ことなしに、アレルゲンに対する IgE 応答を弱めたり消失させ るためにレクチンを用いることは、アレルギーに対する将来的 な治療法として大いに見込みがある。

\section{E-2. 食物中のレクチンの膵臟に対する影響}

食物中のほとんどのレクチンは外分泌性の膵臟に栄養状態 の変化をもたらす。これは小腸の成長と対応している(表V)。最 もよく知られた例はPHAで、腸と膵臟の両方に対して増殖因子 として働く。膵臟に栄養を与えるレクチンの効果は主にコレシ ストキニン $(\mathrm{CCK})$ が仲介する。コレシストキニンは十二指腸の 腸内分泌細胞からPHAの刺激によって遊離される。膵臓細胞の 増殖は組織におけるポリアミンの代謝と密接に関係している (表 V)。しかし、レクチンによって誘導されるポリアミン依存的 な膵臟の増殖のメカニズムには、ホルモンを介した経路が含ま れるようである。この経路もダイズトリプシンインヒビターが 刺激する経路のどちらも、コレシストキニンを介する点では共 通であるが、少なくとも一部では異なるようである (33)。

膵臟からの消化酵素の分泌は慢性膵炎ではひどく減ってい るので、低濃度の無毒レクチンを投与して膵臓を肥大させるの は、臨床的に実用化できるかもしれない。なぜならば、トリプ シンインヒビターと異なり、レクチンは膵臓のタンパク質分解 
pancreatic proteases and, therefore, the secreted enzymes remain active and contribute to the digestion of nutrients in the small intestine.

\section{E-3. Effects on Hormone Balance}

PHA affects the endocrine pancreas and interferes with insulin secretion and thus changes the hormone balance of the body (33). SBA is also a growth factor for pancreas, but as it does not affect circulating insulin levels, its action is confined to the exocrine pancreas.

Most of the effects of lectins on systemic metabolism are mediated through changes in insulin levels. Thus, insulin concentration is depressed in rats fed on kidney bean diets or intubated with pure PHA but the absence of changes in blood glucose indicates that the animals are not diabetic (34). As a single acute oral dose of PHA also leads to a significant but transient decrease in blood insulin, this reduction is not due to inadequate nutrition but probably is a direct effect of the lectin on insulin synthesis and/or secretion by the pancreas.

To compensate for the depression of blood insulin levels, various homeostatic processes are activated by PHA, including changes in other hormone levels such as changes in glucagon (2) and glucocorticoid levels. It is therefore clear that PHA does not only modulate insulin levels but can also induce complex changes in hormone balance of the body.

It is generally believed that eating legume proteins is beneficial for human health because they appear to reduce the concentration of plasma and body lipids. Although it is not clear whether lectins are involved in this process, it is known that PHA and other lectins $(2,35)$ are potent lipolytic agents.

\section{E-4. Effects on Peripheral Organs and Tissues}

Skeletal muscle: PHA and several other lectins have long been known to mimic most of the in vitro biological effects of insulin $(36,37)$. PHA also binds to the insulin receptor of muscle cells (2), but unlike insulin, it does not stimulate protein synthesis in this tissue. At very high oral intakes of PHA (over $0.5 \mathrm{~g} \mathrm{~kg}-1$ body weight) this results in a loss of about $30 \%$ of skeletal muscle in rats fed kidney bean diets for ten days (25). One of the main causes of muscle catabolism is the reduction of the fractional rate of protein synthesis which occurs without a similar decrease in protein degradation rate, thus leading to a net loss of muscle protein (38). These results suggest that the muscle atrophy is the consequence of the abrogation of the stimulatory effect of insulin on muscle protein synthesis because the receptor sites for insulin are blocked by PHA. However, muscle wastage is not as extensive as could be expected from the low blood insulin concentration, because a parallel compensatory upregulation of the mRNA of the insulin-receptor and insulin-sensitive glucose transporter by the dietary PHA increases the efficiency of insulin-receptor interaction (39). Despite these compensatory changes, large amounts of nutrients and polyamines are released from the atrophying
酵素を阻害しないので、分泌された酵素は活性を保ち、小腸に おける食物の消化に貢献できるからである。

\section{E-3. ホルモンバランスへの影響}

PHAは内分泌性の膵臟に影響を与え、インスリン分泌を妨 害するので、体のホルモンバランスを変えてしまう (33)。SBA も膵臓に対して増殖因子として働くが、循環するインスリンレ ベルには影響を与えないので、その作用は外分泌性の膵臓に対 してのみに限定される。

全身代謝へのレクチンの効果のほとんどはインスリンレベ ルの変化による。インゲンマメを食餌として与えられたラット や、純粋なPHAを管を使って与えられたラットではインスリン 濃度は抑えられている。しかし、血中グルコース濃度が変化し ないことからこのラットは糖尿病にはなっていない (34)。PHA を一回だけ突発的に経口投与しても、有意ではあるが、一過性 の血中インスリン濃度の減少がみられるので、この減少は栄養 不足によるのではなく、おそらく、インスリン合成または膵臓 からの分泌(あるいはその両方)に対するレクチンの直接の効果 であろう。

血中インスリン濃度の低下を補うために、恒常性維持のた めのいろいろのプロセスがPHAにより活性化される。その中に はグルカゴン (2) やグルココルチコイド濃度の変化など他の木 ルモン濃度の変化も含まれる。それゆえ、PHAはインスリンレ ベルだけを調節するのではなく、体のホルモンバランスの複雑 な変化も誘導できることが明らかである。

マメ類のタンパク質を食べると、血漿中や体内の脂質の濃 度が下がるらしいので、人間の健康によいと一般的に信じられ ている。この過程にレクチンが関与しているかどうかは明らか ではないが、PHAや他のレクチンが脂肪分解を強く促す因子で あることは知られている $(2 、 35) 。$

\section{E-4. 末梢器官や組織への影響}

骨格筋:PHAを含むいくつかのレクチンは、in vitroではイ ンスリンの生物活性のほとんどを模倣することが昔から知られ ている (36、37)。PHAは筋肉細胞のインスリン受容体に結合す ることもできるが(2)、インスリンと違ってタンパク質合成を促 進しない。PHAを経口で大量に椇取した場合 (体重 $1 \mathrm{~kg}$ あたり $0.5 \mathrm{~g}$ 以上)、インゲンマメの慨を 10 日間与えられたラットでは 骨格筋の約 $30 \%$ が失われた (25)。筋肉ではタンパク質合成速度 が減少することが異化作用の主な原因の一つである。タンパク 質分解速度は変化しないので、筋肉タンパク質が全体で見ると 減少する (38)。このことから筋肉の萎縮は、インスリンによる 筋肉タンパク質合成の促進効果が失われた結果として起こるこ とが示唆される。その根拠は、インスリン受容体がPHAで阻害 されるからである。しかし、筋肉の消失は、血中インスリン濃 度の低さから予想されるほど顕著ではない。なぜなら食物中の PHAにより、このことを補償するようにインスリン受容体执よ びインスリン感受性グルコーストランスポーターの mRNA が アップレギュレーションを受け、インスリンと受容体の相互作 用の効率を高好らである (39)。こういった補償的な変化が 起こるにもかかわらず、萎縮しつつある筋肉から大量の栄養分 
muscles and are then used to support the growth of the gut (40).

Thymus, spleen and other organs: At high intake of antinutrient lectins $(2,25)$ the thymus and spleen undergo atrophic changes. Some of these are irreversible with potentially serious consequences for the immune system, especially $T$ cellmediated immunity.

Similar to skeletal muscle, lectins may also affect the heart by reducing its weight and the rate of protein synthesis (38). Some lectins cause a slight reduction in liver weight which is mainly due to losses in lipids and glycogen after ten days of oral exposure to PHA (2). The kidneys are also slightly enlarged in these rats. However, this effect is non-specific as other forms of protein-deprivation lead to similar enlargement. Although these lectin-effects have been observed with animals, it is expected that some of them may also apply to humans.

\section{F. Perspectives of the Use Lectins (Genes) as Natural Insec- ticides in Transgenic Plants}

Lectins appear to have a dual role in the plant; they can serve as convenient forms of nitrogen storage and may also fulfil a defensive-protective function. It is realised that their main function may be to protect plants against pests and, indeed, convincing evidence exists that lectin function and plant protection are correlated.

It is obvious that an individual lectin of defined carbohydrate specificity cannot defend plants against all potential predators because the glycosyl structures expressed on the external surfaces of the different bacteria, fungi, insects and mammals are usually different. Fortunately, as most pests are hostspecific to some extent, it is possible, at least theoretically, for a plant during evolution to acquire lectins with the "right" carbohydrate specificities. However, to be effective, the plant will also need different strategies against each predator and this will depend on both the pest and the plant. To be successful against bacteria and fungi, the lectin will have to be able to stop their attack at an early stage of infection before they can penetrate deeply into plant tissues. This is usually achieved by binding the bacterial or fungal cell wall to the lectin on the surface of the plant. The best examples of these are the chitin-binding proteins of plant tissues, including chitin-binding lectins which, by inhibiting spore germination and hyphal growth, can protect the plants. However, the nature of the interactions between plants and insect and/or higher animal predators is more complex and requires a thorough understanding of the structure and function of the digestive tract of the predator. Animals will first have to eat the plant and it is the consequent harmful effects of the diet which will discourage the predator to go on with the eating (4). However, this type of passive protection has serious consequences for the entire food chain as lectins can also be harmful for the human and higher animal consumers. Lectins protect the plant against insects because, by interacting with surface
とポリアミンが放出され、腸の増殖を助けるために使われる (40)。

胸腺、脾臟とその他の組織: 栄養分にならないレクチンを 大量に摂取すると胸腺と脾臓は萎縮する $(2 、 25)$ 。これらの変化 には非可逆的なものもあり、免疫系、特に $\mathrm{T}$ 細胞を介する免疫 に深刻な結果をもたらす。

心臟に対しても骨格筋の場合と同様に、レクチンはその重 量を減らし、タンパク質合成の速度を低下させて、なんらかの 影響を与えるかもしれない (38)。肝臓の重量をやや低下させる レクチンもあるが、これは主に、PHAを経口搷取させてから 10 日後に脂質とグリコーゲンが減少するのが原因である(2)。こう したラットでは腎臓がわずかながら大きくなっている。しかし、 こうした効果は非特異的である。なぜなら、レクチンが原因で ないタンパク質損失の場合にも同じような肥大が見られたから である。こういったレクチンの効果はヒト以外の動物で見られ たものであるが、そのうちのいくつかはヒトにもあてはまるだ ろう。

F.レクチン(遺伝子)を天然の殺虫剂として利用できるトランス ジェニック植物の開発について

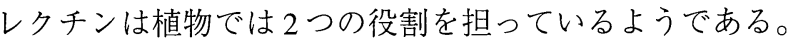
窒素の貯蔵に適していることと、防衛・防禦因子としての機能 が考えられる。レクチンの主要な機能は、おそらく植物を害虫 から守ることにあることがわかりはじめ、実際、レクチンの機 能と植物の防衛能力には関係があるという説得力のある証拠も ある。

ある特定の糖構造に特異性を持つ 1 種類のレクチンが、あ らゆる捕食者から植物を守ることなどできないことは明らかで ある。なぜなら、細菌、菌類、昆虫、哺乳類などでは生物種が 異なれば、表面に発現している糖構造も異なるのがふつうだか らである。幸いなことに、害虫のほとんどが、ある程度宿主特 異的なので、少なくとも理論的には、植物が進化の過程で「正 しい」糖特異性を持ったレクチンを手に入れることは可能だっ た。しかし、防禦システムが効果的であるためには、植物はそ れぞれの侵略者に対して異なった戦略を持つ必要があり、これ は害虫と植物の両方に依存する。細菌や菌類に対しての防禦が 成功するためには、レクチンはそれらが植物の組織に深く入り 込む前の感染の初期段階で攻撃を止めることができなければな らない。この目的を達成するために、植物表面のレクチンが細 菌や菌類の細胞壁を結合する。最も適当な例は植物組織のキチ ン結合タンパク質であり、これにはキチン結合レクチンも含ま れる。キチン結合レクチンは、菌類の胞子の発芽と菌系の成長 を阻害して植物を守る。しかし、昆虫や高等動物のような捕食 者と植物との相互作用ははるかに複雑な様相を呈し、捕食者の 消化管の構造と機能を完全に理解することが必要である。動物 はその植物をまず食べなければならないが、食物の有害な影響 がでたならそれ以上食べ続けることを断念するだろう(4)。しか し、こうした受け身の防禦は食物連鎖全体に深刻な影響をもた 
saccharides of cell membrane glycoconjugates in the insect gut, they interfere with food assimilation and metabolism in the pest. However, if the lectin reacts in a similar fashion with the mammalian gut epithelium, it is likely that similarly antinutritive or occasionally toxic effects will follow. Thus, there is an inextricable link between lectin-mediated protection of plants against predators and the potential nutritional problems of prospective mammalian consumers of the plants.

In conclusion, transgenic research is now focussing on the identification of lectin genes which are suitable for transfer into plants to enhance their resistance towards insect and nematode pests, but have minimum impact on non-target, beneficial organisms, the environment and livestock feeding on these plants, and which present no health risks for humans either directly or indirectly the food chain.

\section{Acknowledgement}

PA is a Senior Research Fellow of The Rowett Research Institute and this work has been financed by the Scottish Office Agriculture, Environment and Fisheries Department.
らす。なぜなら、レクチンは連鎖の上位で植物を消費している ヒトなどの動物にとっても有害となってしまうからである。レ クチンは、昆虫の腸の細胞膜複合糖質の表面糖鎖と相互作用す ることにより、害虫における食物の消化と代謝を妨害し、植物 を昆虫から守る。しかし、レクチンが哺乳類の腸の上皮と同じ ように反応したとすると、やはり栄養にはならず、ひどいとき には毒になる。それゆえ、植物を食べる昆虫に対するレクチン の防衛作用と、同じく植物を利用する哺乳動物に起こりうる栄 養上の問題は密接に結びついている。

植物に導入した場合、昆虫や線虫などの害虫に対しては抵 抗性が増す一方で、排除する対象ではない有益な生物や環境に 対しては最小限の影響しか及ぼさず、家畜の餌として害がなく、 しかも食物連鎖によって人間に取り达まれようが、人間が直接 摄取しようが健康上のリスクがない、そんなレクチンの遺伝子 を見つけることが、現在のトランスジェニック技術の研究の目 標である。

\section{帝京大学薬学部・生物化学教室}

荒田 洋一郎 訳

\section{References}

1. Kocourek, J., and Horejsi, V. (1983) in Lectins, Biology, Biochemistry, Clinical Biochemistry (Bog-Hansen, T.C., and Spengler, G.A. eds.) Vol. 1, pp. 3-6, Berlin and New York, Walter de Gruyter.

2. Pusztai, A. (1991) in Plant Lectins, Cambridge, Cambridge University Press

3. Pusztai, A. (1993) Eur. J. Clin. Nutr. 47, 691-699

4. Gatehouse, A.M.R., Powell, K.S., Peumans, W.J., Van Damme, E.J.M., and Gatehouse, J. (1995) in Lectins Biomedical Perspectives (Pusztai, A., and Bardocz, S. eds.) pp. 35-57, London, Taylor \& Francis

5. Pusztai, A., Ewen, S.W.B., Grant, G., Peumans, W.J., Van Damme, E.J.M., Rubio, L.A., and Bardocz, S. (1991) in Lectin Reviews (Kilpatrick, D.C., Van Driessche, E., and Bog-Hansen, T.C. eds.) Vol.1, pp. 1-15, St.Louis, Sigma

6. Pusztai, A., Ewen, S.W.B., Grant, G., Peumans, W.J., Van Damme, E.J.M., Rubio, L., and Bardocz, S. (1990) Digestion 46(suppl. 2), 308316

7. Pusztai, A., Ewen, S.W.B., Grant, G., Peumans, W.J., Van Damme, E.J.M., Coates, M.E., and Bardocz, S. (1995) Glycoconj. J. 12, 22-35

8. Roth. J. (1987) Biochim. Biophys. Acta 906, 405-436

9. Taatjes, D.J., and Roth, J. (1991) Int. Rev. Cytol. 126, 135-193

10. Roth, J. (1993) Histochem. J. 25, 687-710

11. Banwell, J.G., Howard, R., Kabir, I., Adriab, T.E., Diamond, R.H., and Abramowsky, C. (1993) Gastroenterology 104, 1669-1677

12. Sessa, A., Tunici, P., Ewen, S.W.B., Grant, G., Pusztai, A., Bardocz, S., and Perrin, A. (1995) Biochim. Biophys. Acta 1244, 198-202

13. Pusztai, A., Ewen, S.W.B., Grant, G., Brown, D.S., Stewart, J.C., Peumans, W.J., Van Damme, E.J.M., and Bardocz, S. (1993) Brit. J. Nutr. 70, 313-321

14. Bardocz, S., Grant, G., Ewen, S.W.B., Duguid, T.J., Brown, D.S., Englyst, K., and Pusztai, A. (1995) Gut, 37, 353-360

15. Hsu, S.M., and Raine, L. (1982) Am. J. Clin. Pathol. 77, 396-400

16. Pusztai, A. (1995) Proc. Int. Symp. Control. Rel. Bioact. Mater. 22, 161-162

17. Greer, F., and Pusztai, A. (1985) Digestion, 32, 42-46

18. Pusztai, A., Begbie, R., Grant, G., Ewen, S.W.B., and Bardocz, S. (1991) in In vitro Digestion for Pigs and Poultry (Fuller, M.F. ed.) pp. 4561, Wallingford, Oxon, $\mathrm{CAB}$ International

19. Jayne-Williams, D.J., and Burgess, C.D. (1974) J. Appl. Bacteriol. 37, 149-169

20. Rattray, E.A.S., Palmer, R., and Pusztai, A. (1974) J. Sci. Food Agric. 25, 1035-1040

21. Wilson, A.B., King, T.P., Clarke, E.M.W., and Pusztai, A. (1980) J. Comp.Pathol. 90, 596-602

22. Ceri, H., Falkenberg-Anderson, K., Fant, R., Costerton, J.W., Howard, R., and Banwell, J.G. (1988) Can. J. Microbiol. 34, 1003-1008

23. Banwell, J.G., Howard, R., Kabir, I., and Costerton, J.W. (1988) Can. J. Microbiol. 34, 1009-1013

24. Pusztai, A., Grant, G., Spencer, R.J., Duguid, T.J., Brown, D.S., Ewen, S.W.B., Peumans, W.J., Van Damme, E.J.M., and Bardocz, S. (1993) J. Appl. Bacteriol. 75, 360-368

25. de Oliveira, J.T.A., Pusztai, A., and Grant, G. (1988) Nutr. Res. 8, 943-947

26. Pusztai, A., Greer, F. and Grant, G. (1989) Biochem. Soc. Trans. 17, 527-528

27. Pusztai, A., Clarke, E.M.W., Grant, G., and King, T.P. (1981) J. Sci. Food Agric. 32, 1037-1046

28. de Aizpurua, H.J., and Russel-Jones, G.J. (1988) J. Exp. Med., 167, 440-451

29. Koshte, V.L., Aalbers. M., Calkhoven, P.G., and Aalberse, R.C. (1992) Int. Arch. Allergy Immunol., 97, 17-24 
30. Gollapudi, V.S.S., and Kindl, L.S. (1975) Int. Arch. Allergy Appl. Immunol. 48, 94-100

31. Astorquiza, M., and Sagayo, S. (1984) Int. Arch. Allergy Appl. Immunol. 76, 367-369

32. Restum-Miquel, N., and Provoust-Danon, A. (1985) Immunology 54, 497-504

33. Pusztai, A., Ewen, S.W.B., Grant, G., Brown, D.S., Peumans, W.J., Van Damme, E.J.M., and Bardocz, S. (1992) in Polyamines in the Gastrointestinal Tract (Dowling, R.H., Fîlsch, U.R., and Lîser, C. eds.) pp. 473-483,, Dordrecht, Kluwer Academic Publishers

34. Pusztai, A., Ewen, S.W.B., Carvalho, A.F.F.U., de, Grant, G, Stewart, J.C., and Bardocz, S. (1991) Euro Food Tox III. Proc. Interdisciplinary Conf. on "Effects of Food on the Immune and Hormonal Systems", pp. 20-24, Zürich, Switzerland

35. Ng, T.B., Li, W.W., and Yeung, H.W. (1989) Int. J. Biochem. 21, 149-155

36. Pusztai, A., and Watt, W.B. (1974) Biochim. Biophys. Acta 365, 57-71

37. Cuatrecasas, P., and Tell, G.P.E. (1973) Proc. Natl. Acad. Sci. USA 70, 485-489

38. Palmer, R., Pusztai, A., Bain, P., and Grant, G. (1987) Comp. Biochem. Physiol. 88C, 179-183

39. Knott, R.M., Grant, G., Bardocz, S., Pusztai, A., de Carvalho, A.F.F.U., and Hesketh, J. (1992) Int. J. Biochem. 24, 897-902

40. Bardocz, S., Brown, D.S., Grant, G., Pusztai, A., Stewart, J.C., and Palmer, R.M. (1992) Brit. J. Pharmacol. 106, $476-482$

Received on January 12, 1996, accepted on February 8, 1996 